\title{
UMA TRAJETÓRIA ATLÂNTICA
}

\author{
Jorge Lucas Simões Minella*
}

REIS, João José; GOMES, Flávio dos Santos; MARCUS, J. M. de. O Alufá Rufino: tráfico, escravidão e liberdade no Atlântico negro (c. 1822 - c. 1853). São Paulo: Companhia das Letras, 2010.

Tráfico, escravidão e liberdade. O subtítulo do livro alerta para a própria trajetória de Rufino José Maria, figura atlântica, escravizado, alforriado e que, como liberto, esteve envolvido em viagens transatlânticas de traficantes de escravos. A trajetória de Rufino não marca apenas os caminhos e descaminhos de um personagem atlântico, mas determina também a trajetória da historiografia do próprio livro, em sua perseguição retrospectiva à figura do alufá e os diferentes contextos pelo qual passou. O tráfico, a escravidão e a liberdade no Atlântico negro passam a ser não apenas temas que caracterizam sua biografia, mas objetos históricos centrais alcançados pelos historiadores através da busca por Rufino.

Essa é a proposta dos autores João José Reis, da Universidade Federal da Bahia, autor de Rebelião Escrava no Brasil: a história do levante dos malês e Domingos Sodré: um sacerdote africano, entre outras obras; Flávio dos Santos Gomes, da Universidade Federal do Rio de Janeiro, autor de Histórias de quilombolas: mocambos e comunidades de senzalas no Rio de Janeiro do Século XIX; e Marcus de Carvalho, da Universidade Federal de Pernambuco, autor de Liberdade: rotinas e rupturas do escravismo, Recife, 1822-1850. Os três, portanto, estudiosos do tema da escravidão, cada um deles tendo trabalhado sobre este tema em um dos diversos lugares em que esteve Rufino; Salvador, Rio de Janeiro e Recife.

* Mestrando no Programa de Pós-Graduação em História da Universidade Federal de Santa Catarina (UFSC).E-mail: jorgeminella@gmail.com 
Em certo sentido, Rufino, com seu peculiar trânsito geográfico, serve como guia dos historiadores para uma investigação de um contexto histórico bastante amplo. Sua trajetória não pode ser totalmente reconstruída, mas suas aparições documentais, ora em Recife, ora no Rio Grande do Sul, ou em Serra Leoa, por exemplo, abrem caminho para um estudo histórico de um ambiente dinâmico, marcado pelo trânsito atlântico, que supera uma historiografia regional ou nacional. Podemos encarar a perseguição de seu trajeto como um método de investigação acerca deste amplo contexto. Essa historiografia atlântica tem como ponto de partida um grupo pequeno de documentos: essencialmente o depoimento do alufá à polícia do Recife e seus desdobramentos. Deste núcleo básico, outros documentos foram obtidos no processo de rastreamento retrospectivo de seus caminhos, permitindo uma reconstrução do contexto dos diferentes lugares pelos quais passou.

Sua história começa na África, no reino de Oyó, parte interior do Golfo de Benin. Deste modo, seguindo os primeiros passos de seu guia, os historiadores nos trazem a história desse reino escravista, uma mistura de orixás e muçulmanos na primeira metade do século XIX. Rufino, chamado Abuncare em sua terra, viveu no conturbado período próximo do ano 1817, quando uma revolta de escravos desestabilizou o reino, e trouxe à tona conflitos religiosos. Em declaração à polícia de Recife, afirmou ter sido capturado nesta situação conflituosa por um grupo muçulmano rival da sua própria comunidade, também muçulmana, e vendido como escravo, sendo então transportado para a Bahia em 1822 ou no ano seguinte, em meio aos conflitos de independência daquela província.

Ele reaparece em Salvador, onde é comprado pelo boticário João Gomes da Silva, figura importante na cidade, bem relacionado, e fornecedor dos remédios da Santa Casa de Misericórdia. A aparição de Rufino neste local permite, seguindo o método, um estudo de vários aspectos sociais da época: as atividades de seu senhor e as estratégias de manutenção do seu plantel de escravos, sua rede social, a composição de sua família, a demografia do tráfico em Salvador em um período em que ele já estava proibido acima da linha do equador, as ocupações dos escravos urbanos. Rufino, como muitos escravos urbanos, cumpriu a função de cozinheiro, mas pode ter distribuído suas funções também entre a botica e a rua. As revoltas de escravos na Bahia também aparecem nesta parte da narrativa. O próprio Rufino, como malê, poderia ter se envolvido em uma das maiores revoltas de escravos da época, a chamada Revolta dos Malês, em 1835. Neste ano, porém, ele não estava mais na Bahia; fora levado para o Rio Grande do Sul por um filho de seu senhor, entre 1830 e 1831.

Como de praxe, Rufino serve de pretexto para um breve estudo sobre a escravidão naquela província sulina e o tráfico interno de escravos das 
províncias do norte para as do sul. Lá ele é comprado pelo desembargador José Maria Peçanha, que utiliza Rufino como cozinheiro em Porto Alegre. Outra vez temos a história de seu senhor, a demografia escrava da província e da cidade, marcada por escravos de ganho, quitandeiras, carregadores de fardos, etc. Também temos os inúmeros conflitos entre escravos e senhores ocorridos na região. No final de 1835, com a eclosão do conflito Farroupilha, Rufino obteve sua alforria, pela qual alegou ter pagado 600 mil réis a seu senhor. Esse episódio fundamental na vida do escravo, agora liberto, é um tanto obscuro, talvez pela falta de documentação, e a situação de seu senhor diante da Guerra dos Farrapos não fica clara.

Aqui, porém, se manifesta com bastante clareza o que parece ser uma das questões mais ricas do livro: o manuseio das possibilidades. Os autores sugerem a possibilidade, graças a um documento encontrado que indicava os nomes de dois negros expulsos da província na época, um deles de nome Rufino, dele ter estado, após Porto Alegre, em Rio Grande, de onde teria sido deportado, por envolvimento com uma escola muçulmana fechada pela policia em 1838. Não há como confirmar a identidade deste Rufino, uma vez que o nosso personagem teria bons motivos para omitir este episódio em seu depoimento à polícia de Recife. Os autores apresentam essa deportação como uma possibilidade que volta e meia é retomada. Não há como afirmar categoricamente se tal evento ocorreu ou não; é possível apenas cercá-lo com a escassa documentação disponível e uma sequência de conjecturas razoáveis. O fundamental, ao lidar com a possibilidade, é fazê-lo de forma intelectualmente honesta, ou seja, não tentar disfarçar as conjeturas como se fossem fatos, e sim elucidá-las, marcando o que é apenas possível e o que certamente aconteceu. Isso os autores fazem, durante todo o livro, com precisão.

Isso nos leva a pensar o papel fundamental que a linguagem da possibilidade cumpre na atividade do historiador. Entendo que escrever historia é, também, lidar com lacunas. O passado nunca se apresenta por completo, esperando alguém que possa narrá-lo; ao contrário, as fontes sempre deixam espaços. A história, porém, não pode se deter diante da lacuna. Se assim fosse ela não passaria de uma enumeração de documentos. Ela não é uma verdade rígida, que se recusa a transpor o campo da certeza, mas tampouco é um jogo sem regras; a possibilidade não é fruto de devaneios do historiador, mas de sua argumentação articulada com as fontes disponíveis.

Independente de Rufino ter sido ou não expulso do Rio Grande Sul, ele foi parar no Rio de Janeiro, agora como liberto. Mais uma vez, a presença dele abre a discussão do contexto. A capital do Império tinha uma imensa população negra, entre escravos e libertos, porém poucos eram minas, ou seja, originários da região do Golfo de Benin, como Rufino. A maioria era da região de Angola, Congo ou Moçambique. A pergunta sobre os motivos que levaram Rufino a 
trabalhar em um navio de águas profundas permite pensar alguns aspectos da situação da pequena população malê do Rio. A revolta ocorrida na Bahia em 1835 teria espalhado o medo de que os malês pudessem novamente se revoltar, dificultando a vida de Rufino que, ademais, como cozinheiro, tinha um trabalho que o colocava muito próximo do empregador e sua família. Além disso, o fluxo de escravos e libertos da Bahia para o Rio de Janeiro era muito grande, saturando o mercado de trabalho. Em uma cidade sem emprego e sob suspeita constante por ser malê, o mar pode ter sido para Rufino, se não a única, ao menos a melhor alternativa. Além de tudo, apontam os autores, marinheiros negros ex-escravos eram bastante comuns na cidade portuária do Rio.

Ele se torna, então, cozinheiro de navio negreiro. Inicia sua "carreira" na escuna Paula, partindo do Rio tendo como destino provável Angola, de onde retorna para o Recife no patacho São José. Seu ingresso no tráfico é o pretexto para que os historiadores entrem no tema desta atividade atlântica, descrevendo a degradante situação dos cativos nos navios, chamados tumbeiros, e a imensa rede mobilizada para a atividade do tráfico já no período em que este já havia sido proibido, com os navios sendo perseguidos por embarcações inglesas na costa da África. A última viagem de tráfico de Rufino, agora não apenas como cozinheiro, mas como pequeno comerciante atlântico de goiabada, seria interrompida pelo brigue Inglês Water Witch, no litoral de Luanda, Angola.

Antes, porém, os historiadores usam o Ermelinda, navio desta última viagem, como um exemplo das dimensões do tráfico, aproveitando que sua captura deixou marcas documentais. A grande quantidade de mercadorias embarcadas no navio, incluindo cachaça e um artigo de luxo para um empresário de Luanda envolvido com o tráfico, indicam os tipos de trocas atlânticas. A própria cidade de Luanda, entreposto do tráfico, é descrita pelos historiadores ao seguirem os rastros de Rufino: uma cidade enriquecida pelo tráfico, onde os europeus estabeleciam contatos com reinos de Angola e trocavam seus produtos por negros capturados. Os historiadores têm que lidar com o fato de que, por ser o tráfico uma atividade ilegal, os esforços para seu acobertamento eram grandes, dificultando o trabalho retrospectivo. Uma pesquisa pelos donos dos navios nos quais Rufino trabalhou revela o caráter empresarial do tráfico; segundo as investigações a empresa para qual Rufino trabalhou como cozinheiro de navio era gerenciada por certo José Francisco de Azevedo Lisboa, o Azevedinho, residente no Recife. Ele era o articulador de uma rede cujos tentáculos saíam de Pernambuco, passavam pela capital do Império, atravessavam o Atlântico em direção à Luanda, e até mesmo contava com a promiscuidade dos árbitros brasileiros na comissão mista de Brasil e Inglaterra para combate ao tráfico, sediada em Serra Leoa, colônia inglesa criada para abrigar escravos libertos.

É para Serra Leoa que Rufino é levado, junto com a Ermelinda. Lá a barca foi julgada pela comissão mista, para determinar se estava ou não realizando 
tráfico de escravos, uma vez que fora capturada ainda a caminho da África, sem escravos, portanto. São três os aspectos trabalhados pelos historiadores acerca deste momento da vida de Rufino. Primeiro sua própria experiência em Serra Leoa e seu envolvimento com a representativa comunidade muçulmana na colônia. Foi aí que, segundo seu depoimento, terminou seus estudos da língua árabe e do islã. Assim, sua primeira passagem em Serra Leoa é um passo fundamental para sua ocupação como Alufá, ou seja, "uma espécie de padre e mestre de escola, que além do ensino de preceitos religiosos exerce outros misteres" em Recife, alguns anos mais tarde (p. 18).

Segundo, o quadro geral da colônia, sua insalubridade, os conflitos internos entre os diferentes grupos africanos concentrados no lugar, subjugados pela lógica do Império Britânico.

Terceiro, o processo de julgamento da Ermelinda pela comissão mista, o que permite relativizar a pureza das intenções abolicionistas inglesas, associando-as a um projeto colonial amplo, e ao esforço até mesmo ilegal dos árbitros ingleses para a condenação do navio, com a implantação clandestina de correntes de escravos na barca para que ela pudesse ser condenada pelo equipment act. Revela-se também a promiscuidade dos árbitros brasileiros, que orientaram o capitão da Ermelinda sobre como fazer para não ser condenado. Algo bastante curioso é a bizarrice jurídica da decisão de que a barca não era boa presa: diante da discordância entre árbitros ingleses e brasileiros, os primeiros querendo condenar, e os outros absolver, a decisão foi por sorteio, e ganhou a absolvição. Mais tarde Rufino voltaria a Serra Leoa para acompanhar o processo do pedido de indenização feito pelos donos do navio e seus carregadores à coroa britânica, revelando a ousadia dos traficantes. Este tipo de pedido era bastante comum, segundo os historiadores.

Os autores assinalam que Rufino encerra sua carreira no tráfico após esse episódio. Os anos de cozinheiro, carregador e possivelmente pequeno traficante, estavam terminados. Ele escolheu o Recife para se estabelecer em terra firme, vivendo no bairro portuário e envolvido com a pequena comunidade nagô da cidade, onde pôde ocupar uma posição de destaque, pela sua educação religiosa, como alufá. Na cidade estabeleceu uma ampla clientela, que incluía não-muçulmanos e brancos. Ele foi preso pela polícia do Recife em 1853, em um clima de suspeita acerca do chamado Ronco do Marimbondo, uma revolta escrava que eclodiu quando foram espalhados boatos de que o censo populacional que o governo pretendeu implantar um ano antes serviria para reescravizar os libertos. As suspeitas naturais recaíam sobre malês, e então Rufino teve sua casa investigada, onde foram encontrados seus escritos em árabe e ele foi, por isso, levado à delegacia como suspeito. Feito seu depoimento e com base em traduções de trechos dos escritos, que nada mais eram que preceitos 
religiosos, ele foi liberado, deixando para os historiadores este documento policial que possibilitou a abertura de sua história.

O livro termina com a importante consideração de que a história de Rufino José Maria permite observar algumas das possibilidades com as quais se deparava o negro liberto no Brasil, inclusive a de associar-se ao tráfico negreiro. Mostra também, ao considerar os motivos de sua escolha de permanecer no Brasil oficialmente "branco cristão", hostil à sua religião, as nuances presentes dentro deste quadro geral: o africano já era ladino no Brasil. Poderia ter, por exemplo, permanecido em Serra Leoa, com a comunidade muçulmana, mas já tinha uma rede social construída no Brasil e uma rede em Recife, que poderia incluir, também, os empresários do tráfico para quem trabalhou. Para ele, talvez, África desmembrada pelo tráfico fosse mais estranha do que o Brasil onde construíra sua vida, mesmo estando boa parte dela em trânsito pelo Atlântico.

Conclui-se, assim, a rica trajetória atlântica de Rufino e dos historiadores que o seguiram, levantando os fatos, as possibilidades e explorando as lacunas históricas. Em poucas palavras, explorando o riquíssimo contexto atlântico do século XIX a partir do Alufá Rufino.

Resenha recebida em agosto de 2011. Aceita em dezembro de 2011. 